\title{
Subarachnoidally administered hyperbaric morphine, buprenorphine, methadone, and $10 \%$ dextrose on cardiopulmonary function and behavior in horses
}

\author{
Administração subaraquenóide de morfina, buprenorfina, metadona hiperbáricos e dextrose $10 \%$ sobre as \\ funções cardiopulmonar e comportamental em cavalos
}

\author{
Cláudio Corrêa Natalini ${ }^{1}$ Renata Lehn Linardi ${ }^{1}$ \\ Alexandre da Silva Polydoro ${ }^{2}$
}

\begin{abstract}
The study was done to compare the heart rate, arterial blood pressure, arterial blood gases, respiratory rate, body temperature, and behavior after subarachnoid administration of hyperbaric morphine (MorphineD10), buprenorphine (BuprenorphineD10), methadone (Methadone D10), and $10 \%$ dextrose (D10) in conscious horses. Six adult horses were studied. Treatments were administered into the lombo-sacral subarachnoid space through an epidural catheter, MorphineD10 at $0.01 \mathrm{mg} \mathrm{kg}^{-1}$, BuprenorphineD10 at $0.001 \mathrm{mg}$ $\mathrm{kg}^{-1}$, MethadoneD10 at $0.01 \mathrm{mg} \mathrm{kg}^{-1}$, and $10 \%$ dextrose as a control group. The results showed that there are minimum changes in heart and respiratory rate, blood gases, blood pressure, and body temperature after subarachnoid administration of hyperbaric opioids in horses. No sedation and nor motor impairment or behavioral changes occur.
\end{abstract}

Key words: morphine, methadone, buprenorphine, hyperbaric opioid, subarachnoid.

\section{RESUMO}

$O$ estudo foi realizado com a finalidade de comparar a freqüência cardíaca, a pressão sanguínea arterial, à análise de gases, a freqüência respiratória, a temperatura corpórea e o comportamento de eqüinos após a administração subaraquenóide de morfina hiperbárica (MorfinaD10), buprenorfina hiperbárica (BuprenorfinaD10), metadona hiperbárica (MetadonaD10) e dextrose 10\% (D10). As doses de MorphinaD10 (0.01 $\left.\mathrm{mg} \mathrm{kg}^{-1}\right)$, BuprenorfinaD10 $(0.001 \mathrm{mg}$ $\mathrm{kg}^{-1}$ ), MetadonaD10 (0.01 $\mathrm{mg} \mathrm{kg}^{-1}$ ) e dextrose 10\% (grupo controle, $5 \mathrm{ml}$ ) foram administradas no espaço subaracnóide da região lombo-sacra de seis cavalos adultos, por meio de um catéter epidural. Os resultados mostraram alterações mínimas nas freqüências cardíaca e respiratória, na análise de gases, na pressão arterial e na temperatura corpórea após a administração subaracnóide de opióides hiperbáricos em cavalos. Os animais não apresentaram sedação, ataxia nem alteração comportamental.

Palavras-chave: morfina, metadona, buprenorfina, opióide hiperbárico, subaracnóide.

\section{INTRODUCTION}

Caudal spinal anesthesia or analgesia was first described in 1925 and is well established (PAPE \& PITZSCHK, 1925; McLEOD \& FRANK, 1927).

Spinal analgesia is obtained with different drugs (VALVERDE et al., 1990; SKARDA, 1996; GOMEZ DE SEGURA et al., 1998). Although these are administered in the epidural or subarachnoid space, systemic effects occur due to absorption from the tissues (COUSINS \& MATHER, 1984; SKARDA \& MUIR, 1996; CHENG et al., 1999). Xylazine and its combination with lidocaine have been reported to produce none or minimal cardiovascular depression when epidurally (LeBLANC \& CARON, 1990; LeBLANC \& EBERHART, 1990; GRUBB et al., 1992; SKARDA \& MUIR, 1996). Epidural detomidine in horses was found to produce cardiovascular depression and recumbency (SKARDA \& MUIR, 1994; 1996; WITTERN et al., 1998). Spinal ketamine produced sedation but no cardiovascular depression in horses (GOMEZ DE SEGURA et al., 1998). When compared to other drugs, opioids present advantages over local anesthetic and alpha-2 adrenergic agonists because

\footnotetext{
${ }^{1}$ Department of Veterinary Clinical Sciences, School of Veterinary Medicine, Louisiana State University, Baton Rouge, LA 70803, USA. Email address: cnatalini@vetmed.lsu.edu.

${ }^{2}$ Universidade Federal de Santa Maria (UFSM), Programa de Pós-graduação em Medicina Veterinária, Campus Camobi, 97105-900, Santa Maria, RS, Brasil.
} 
motor impairment or sympathetic blockade does not occur with their use (SINATRA et al., 1992; STOELTING, 1999). The use of a hyperbaric solution is indicated when a more segmental effect is desired. Local anesthetic hyperbaric solutions are commonly used subarachnoidally in human beings (COUSINS \& MATHER, 1984, SINATRA et al., 1992; STOELTING, 1999). The use of an opioid hyperbaric solution has not been described in man or animals.

In human beings, respiratory depression is a concern after epidurally administered opioids (COUSINS \& MATHER, 1984; SINATRA et al., 1992; STOELTING, 1999). Other complications in people are nausea and vomiting, itching, urinary retention, somnolence, central nervous system excitation, and water retention (CHUNG \& HARRIS, 1992; SINATRA et al., 1992). Epidural administration of $0.05 \mathrm{mg} \mathrm{kg}^{-1}$ or $0.1 \mathrm{mg} \mathrm{kg}^{-1}$ morphine produced sedation and long-term complete analgesia in horses and the investigators did not report any major physiologic changes in cardiovascular, respiratory, or gastrointestinal function. Late respiratory depression that is commonly observed in human beings has not been implicated as a complication after spinal opioid administration in small and large animals (PABLO, 1993; THURMON et al., 1996; PADDLEFORD, 1999).

Sympathetic stimulation and central nervous system (CNS) excitation is observed when opioids are systemically administered in horses. Narcotics such as morphine, fentanyl, pentazocine, and butorphanol are potent locomotor stimulants in the horse, when administered intravenously (TOBIN, 1978; 1981; TOBIN \& MILLER, 1979; TOBIN et al., 1979; COMBIE et al., 1979, 1981; KARMELING et al., 1985).

The objective of this study was to comparatively evaluate the cardiovascular, respiratory, and behavioral effects of subarachnoidally administered hyperbaric morphine, buprenorphine, and methadone in horses.

\section{MATERIAL AND METHODS}

Six healthy adult horses from a university teaching herd at our facility were used in the study. Horses ranged from 445 to $570 \mathrm{~kg}$ (mean \pm SD, $466 \pm$ $69 \mathrm{~kg}$ ). The protocol was approved by the Louisiana State University School of Veterinary Medicine Institutional Animal Care and Use Committee.

After sedation with $1 \mathrm{mg} \mathrm{kg}^{-1}$ IV xylazine, all horses had the lumbar-sacral vertebral interspace clipped and the skin surgically prepared and covered with a sterile transparent dressinga. The skin, subcutaneous tissue, and muscle at the lumbar-sacral region, the supraspinous and interspinous ligments were locally anesthetized with $2 \%$ lidocaine. A 17 gauge, $17.78 \mathrm{~cm}$ epidural needle with stylet ${ }^{\mathrm{b}}$ was inserted perpendicularly along the median plane of the lumbarsacral intervertebral space until the lumbar-sacral subarachnoid space was reached. After appropriate placement, the bevel of the needle was directed cephalad and $20 \mathrm{~cm}$ of a sterile reinforced epidural anesthesia catheter ${ }^{\mathrm{c}}$ was advanced cranially through the needle into the subarachnoid space. The catheter was flushed with $1 \mathrm{ml}$ of $10 \mathrm{IU} \mathrm{ml} \mathrm{m}^{-1}$ heparinized saline. The catheter was left in place for 28 days.

All horses received randomly all four treatments, at periods no less than 5 days between each treatment. Those involved in collection (RLL) of data and making behavioral observations were blinded as to the identity of the agent being tested. Measurements of response variable took place immediately prior to subarachnoid injection, then at 5 , $10,20,30,40,50,60,90,120,150$, and 180 minutes.

After catheter placement, cerebrospinal fluid (CSF) samples were collected and tested for specific gravity with a refractometer. Specific gravity for equine CSF was determined to be 1006 . Solutions with specific gravity higher then 1006 were considered hyperbaric in relation to equine CSF.

Hyperbaric morphine $0.01 \mathrm{mg}^{\mathrm{kg}^{-1}}$ (morphineD10) ${ }^{\mathrm{d}}$, buprenorphine $0.001 \mathrm{mg} \mathrm{kg}^{-1}$ (buprenorphineD10) ${ }^{\mathrm{e}}$, and methadone $0.01 \mathrm{mg} \mathrm{kg}^{-1}$ (methadoneD10) $)^{\mathrm{f}}$ in equal volume $(5 \mathrm{ml})$ were obtained diluting the opioid with $10 \%$ dextrose $^{\mathrm{g}}$. The control group received $5 \mathrm{ml}$ of $10 \%$ dextrose without opioids. The specific gravity of the solutions was 1043 for $10 \%$ dextrose, 1042 for morphine, 1038 for methadone, and 1034 for buprenorphine.

Heart rate (HR), systolic arterial pressure (SAP), diastolic arterial pressure (DAP), and mean arterial pressure (MAP) were detected using a direct blood pressure monitoring. Respiratory rate (RR) was determined by counting thoracic and abdominal excursions in 1 minute. Arterial blood samples were collected from an indwelling catheter placed prior to subarachnoid injection on the facial transverse artery. Arterial blood gas and electrolyte analyses were done at baseline, 90 and 180 minutes.

Head drooping (head ptosis) was assessed measuring the distance from the muzzle to the floor in $\mathrm{cm}$. Spontaneous locomotor activity was evaluated for failure of muscular coordination and irregularity of muscular action classified as 0 (no change from the baseline), 1 (CNS excitation hypersensitive to manipulation, increased locomotor activity), 2 (motor ataxia, inability to control the coordinate movements 
of the muscles), 3 (sensory ataxia, loss of proprioception between the motor cortex and peripheral nerves).

Sample size calculation was done considering a $\beta$ value of $20 \%$ and $\alpha<0.05$. A minimum of 6 horses was determined as the necessary sample size. Two-way repeated measures analysis of variance (ANOVA) and Bonferroni's test were used for numerical data. For data measured by ranks, Friedman repeated measured analysis of variance test was used. Differences were considered statistically significant at $\mathrm{P}<0.05$.

\section{RESULTS}

The results showed no significant differences for cardiovascular and respiratory variables. Heart rate, blood pressure, respiratory rate, blood electrolytes, and blood gases stayed within normal limits. Heart rate, blood pressures, and respiratory rate decreased from baseline but not significantly. No ataxia, sedation or CNS excitement was observed in the present study. Arterial blood gases and electrolytes did not change during the study time. Transient discomfort showed as skin twitch and turning the head towards the injection site was observed during the injection time which disappeared at the end of the injection (Tables 1, 2 and 3).

All horses were observed for a 4-week period after the study was completed and no signs of adverse effects were detected. None of the horses showed signs of spinal cord toxicity or gastrointestinal abnormalities.

\section{DISCUSSION}

Previous studies on spinal opioids in horses have been limited to epidural administration (SKARDA, 1996; NATALINI \& ROBINSON, 2000).

Administration of mu $\left(\mathrm{OP}_{3}\right)$ opioid agonists producing CNS excitation has been documented in horses (TOBIN, 1978; 1981; TOBIN \& MILLER, 1979; TOBIN et al., 1979; COMBIE et al., 1979; 1981; KARMELING et al., 1985, MAMA et al., 1992). The response to IV opioid agonists in horses is an increase in locomotor activity, monitored by a step-counting method (COMBIE et al., 1979; TOBIN et al., 1979). The increase in locomotor activity probably involves the dopaminergic pathway activation as well as other neurotransmitters in the CNS such as acetylcholine

Table 1 - Mean systolic (SAP), diastolic (DAP), and mean (MAP) arterial blood pressure and standard deviation ( \pm SD) before (Time 0 ) and after (Time 10 to $180 \mathrm{~min}$ ) subarachnoid administration of hyperbaric opioids (morphineD10, bupenorphineD10, and methadoneD10) and $10 \%$ dextrose in horses $(n=6)$

\begin{tabular}{|c|c|c|c|c|c|c|c|c|c|c|c|c|}
\hline \multirow{2}{*}{$\begin{array}{l}\text { Time } \\
\text { (min) }\end{array}$} & \multicolumn{3}{|c|}{ MorphineD10 } & \multicolumn{3}{|c|}{ BuprenorphineD10 } & \multicolumn{3}{|c|}{ MethadoneD10 } & \multicolumn{3}{|c|}{ 10\% Dextrose } \\
\hline & SAP & DAP & MAP & SAP & DAP & MAP & SAP & DAP & MAP & SAP & DAP & MAP \\
\hline \multirow{2}{*}{0} & \multirow{2}{*}{$145 \pm 22$} & \multirow{2}{*}{$75+25$} & \multirow{2}{*}{$107 \pm 18$} & 147 & 79 & 106 & 153 & 82 & 110 & 134 & 90 & 112 \\
\hline & & & & \pm 19 & \pm 12 & \pm 13 & \pm 24 & \pm 19 & \pm 18 & \pm 12 & \pm 15 & \pm 18 \\
\hline \multirow{2}{*}{10} & \multirow{2}{*}{$136 \pm 10$} & \multirow{2}{*}{$73 \pm 21$} & \multirow{2}{*}{$100 \pm 17$} & 138 & 79 & 101 & 137 & 73 & 97 & 129 & 66 & 101 \\
\hline & & & & \pm 16 & \pm 19 & \pm 17 & \pm 17 & \pm 12 & \pm 16 & \pm 12 & \pm 13 & \pm 17 \\
\hline \multirow{2}{*}{20} & \multirow{2}{*}{$138 \pm 20$} & \multirow{2}{*}{$80 \pm 19$} & \multirow{2}{*}{$107 \pm 18$} & 136 & 67 & 96 & 143 & 77 & 104 & 130 & 75 & 102 \\
\hline & & & & \pm 16 & +20 & \pm 18 & \pm 14 & +22 & \pm 23 & \pm 11 & +22 & +22 \\
\hline \multirow{2}{*}{30} & \multirow{2}{*}{$131 \pm 20$} & \multirow{2}{*}{$66 \pm 14$} & \multirow{2}{*}{$88 \pm 19$} & 133 & 69 & 95 & 134 & 67 & 90 & 126 & 63 & 89 \\
\hline & & & & \pm 16 & \pm 16 & \pm 15 & \pm 156 & \pm 16 & \pm 17 & \pm 15 & \pm 18 & \pm 19 \\
\hline \multirow{2}{*}{40} & \multirow{2}{*}{$131 \pm 12$} & \multirow{2}{*}{$69 \pm 16$} & \multirow{2}{*}{$98 \pm 13$} & 132 & 69 & 95 & 136 & 70 & 97 & 127 & 71 & 96 \\
\hline & & & & \pm 14 & \pm 20 & \pm 17 & \pm 14 & \pm 24 & \pm 17 & \pm 13 & \pm 24 & \pm 18 \\
\hline \multirow{2}{*}{50} & \multirow{2}{*}{$132 \pm 9$} & \multirow{2}{*}{$57 \pm 20$} & \multirow{2}{*}{$87 \pm 16$} & 133 & 62 & 89 & 131 & 57 & 83 & 135 & 55 & 85 \\
\hline & & & & \pm 6 & \pm 12 & \pm 5 & \pm 5 & \pm 15 & \pm 11 & \pm 4 & \pm 16 & \pm 11 \\
\hline \multirow{2}{*}{60} & \multirow{2}{*}{$137 \pm 12$} & & & 135 & 67 & 95 & 131 & 79 & 98 & 130 & 82 & 106 \\
\hline & & $81 \pm 32$ & $105 \pm 24$ & \pm 15 & \pm 16 & \pm 15 & \pm 17 & \pm 33 & \pm 29 & \pm 13 & \pm 33 & \pm 26 \\
\hline م & & & & 129 & 63 & 89 & 135 & 67 & 96 & 131 & 69 & 94 \\
\hline 90 & $138 \pm 11$ & $72 \pm 18$ & $103 \pm 16$ & \pm 14 & \pm 16 & \pm 13 & \pm 13 & \pm 19 & \pm 17 & \pm 14 & \pm 20 & \pm 16 \\
\hline 170 & & & & 131 & 64 & 96 & 123 & 58 & 89 & 133 & 56 & 92 \\
\hline 120 & $128 \pm$ & $65 \pm 14$ & $90 \pm 12$ & \pm 13 & \pm 14 & \pm 16 & \pm 9 & \pm 11 & \pm 13 & \pm 16 & \pm 14 & \pm 16 \\
\hline 150 & & & $94+4$ & 125 & 70 & 99 & 131 & 75 & 102 & 121 & 66 & 92 \\
\hline 150 & $130 \pm 10$ & $13 \pm 10$ & $94 \pm 4$ & \pm 22 & \pm 22 & \pm 26 & \pm 23 & \pm 22 & \pm 26 & \pm 19 & \pm 21 & \pm 18 \\
\hline 180 & $129+16$ & $71+2$ & $94+9$ & 126 & 62 & 91 & 121 & 61 & 87 & 130 & 56 & 91 \\
\hline 180 & $129 \pm 16$ & $11 \pm 2$ & $94 \pm 9$ & \pm 20 & \pm 18 & \pm 17 & \pm 18 & \pm 16 & \pm 15 & \pm 23 & \pm 16 & \pm 17 \\
\hline
\end{tabular}

Ciência Rural, v.36, n.5, set-out, 2006. 
Table 2 - Mean heart rate (HR), respiratory rate (RR), and head ptosis and standard deviation ( \pm SD) before (Time 0$)$ and after (Time 10 to $180 \mathrm{~min}$ ) subarachnoid administration of hyperbaric opioids (morphineD10, bupenorphineD10, and methadoneD10) and 10\% dextrose in horses $(n=6)$

\begin{tabular}{|c|c|c|c|c|c|c|c|c|c|c|c|c|}
\hline \multirow[b]{2}{*}{$\begin{array}{l}\text { Time } \\
\text { (min) }\end{array}$} & \multicolumn{3}{|c|}{ MorphineD10 } & \multicolumn{3}{|c|}{ BuprenorphineD10 } & \multicolumn{3}{|c|}{ MethadoneD10 } & \multicolumn{3}{|c|}{ 10\% Dextrose } \\
\hline & HR & $\mathrm{RR}$ & $\begin{array}{l}\text { Head } \\
\text { Ptosis }\end{array}$ & HR & $\mathrm{RR}$ & $\begin{array}{l}\text { Head } \\
\text { Ptosis }\end{array}$ & HR & $\mathrm{RR}$ & $\begin{array}{l}\text { Head } \\
\text { Ptosis }\end{array}$ & HR & $\mathrm{RR}$ & $\begin{array}{l}\text { Head } \\
\text { Ptosis }\end{array}$ \\
\hline 0 & $41+2$ & $22 \pm 2$ & $116 \pm 5$ & $41 \pm 6$ & $23 \pm 6$ & $120 \pm 5$ & $45 \pm 5$ & $21+3$ & $112 \pm 4$ & $40 \pm 3$ & $22 \pm 3$ & $112+2$ \\
\hline 10 & $40 \pm 4$ & $21 \pm 2$ & $112 \pm 7$ & $40 \pm 5$ & $18+3$ & $118 \pm 7$ & $43+5$ & $20+2$ & $117 \pm 3$ & $39 \pm 6$ & $19+3$ & $112+10$ \\
\hline 20 & $39 \pm 4$ & $22 \pm 1$ & $116 \pm 4$ & $40 \pm 3$ & $20 \pm 4$ & $120 \pm 5$ & $39 \pm 4$ & $19+2$ & $118+2$ & $37 \pm 4$ & $20 \pm 4$ & $117 \pm 3$ \\
\hline 30 & $39 \pm 3$ & $21+2$ & $112+4$ & $40 \pm 2$ & $19 \pm 1$ & $119 \pm 8$ & $42+4$ & $21+3$ & $119 \pm 5$ & $39+4$ & $20 \pm 3$ & $116 \pm 7$ \\
\hline 40 & $39 \pm 3$ & $20 \pm 2$ & $112 \pm 4$ & $39 \pm 2$ & $21+3$ & $120 \pm 6$ & $42 \pm 6$ & $19 \pm 2$ & $117 \pm 3$ & $40 \pm 6$ & $21+3$ & $114+5$ \\
\hline 50 & $38 \pm 2$ & $20+3$ & $116 \pm 5$ & $39+4$ & $19 \pm 1$ & $120 \pm 6$ & $42+8$ & $18+3$ & $117 \pm 4$ & $39 \pm 8$ & $20 \pm 3$ & $115 \pm 5$ \\
\hline 60 & $39 \pm 4$ & $19 \pm 3$ & $112+4$ & $40 \pm 2$ & $21+3$ & $117 \pm 8$ & $40 \pm 5$ & $19 \pm 2$ & $118+4$ & $39 \pm 4$ & $19 \pm 3$ & $115 \pm 5$ \\
\hline 90 & $38 \pm 3$ & $19 \pm 2$ & $114+5$ & $39 \pm 4$ & $17 \pm 2$ & $118 \pm 7$ & $40 \pm 5$ & $20 \pm 2$ & $117 \pm 5$ & $38+5$ & $19 \pm 2$ & $113+5$ \\
\hline 120 & $40 \pm 7$ & $18+2$ & $111 \pm 2$ & $39 \pm 2$ & $20 \pm 2$ & $117 \pm 7$ & $39 \pm 5$ & $18+3$ & $116 \pm 5$ & $38 \pm 5$ & $19 \pm 2$ & $113+4$ \\
\hline 150 & $43 \pm 4$ & $20 \pm 3$ & $112 \pm 2$ & $39 \pm 4$ & $20 \pm 2$ & $115 \pm 8$ & $41 \pm 8$ & $20 \pm 2$ & $112 \pm 4$ & $39 \pm 8$ & $21 \pm 2$ & $112 \pm 4$ \\
\hline 180 & $41 \pm 2$ & $20 \pm 4$ & $113 \pm 5$ & $40 \pm 4$ & $19 \pm 2$ & $117 \pm 8$ & $41 \pm 6$ & $18 \pm 2$ & $1167 \pm 4$ & $39 \pm 6$ & $19 \pm 5$ & $115 \pm 5$ \\
\hline
\end{tabular}

and norepinephrine(TOBIN, 1978; COMBIE et al., 1979, COMBIE et al., 1981; TOBIN \& MILLER, 1979; MAMA et al., 1992). Excitation of the CNS was not evident in our study and could be explained by a segmental effect of the opioid solutions from the site of injection when compared to a fast supraspinal opioid receptor occupation after IV administration, or after subarachnoid administration of an isobaric solution. A hyperbaric solution could maintain the opioids in close contact with the spinal cord receptors.
Sedation is reported to be dose related after neuraxial opioid administration in human beings (STOELTING, 1999). Lowering the head (head ptosis) has been described in horses after $0.1 \mathrm{mg} \mathrm{kg}^{-1}$ epidural morphine administration (NATALINI \& ROBINSON, 2000). The differences in head ptosis observed in our study were not statistically significant among the study groups and from baseline.

Respiratory depression or arrest, adult respiratory distress syndrome (ARDS), hypoxemia, and

Table 3 - Mean arterial pH, arterial PaCO2, arterial PaO2 of blood gas analyses, and standard deviation ( \pm SD) before (Time 0) and after (Time 10 to $180 \mathrm{~min}$ ) subarachnoid administration of hyperbaric opioids (morphineD10, bupenorphineD10, and methadoneD10) and $10 \%$ dextrose in horses $(n=6)$.

\begin{tabular}{|c|c|c|c|c|}
\hline Treatment groups & Time (min) & 0 & 90 & 180 \\
\hline \multirow{3}{*}{ MorphineD10 } & $\mathrm{pH}$ & $7.44 \pm 0.01$ & $7.40 \pm 0.02$ & $7.39+0.01$ \\
\hline & $\mathrm{P}_{\mathrm{a}} \mathrm{CO}_{2}$ & $37 \pm 1$ & $38 \pm 5$ & $39 \pm 0.5$ \\
\hline & $\mathrm{P}_{\mathrm{a}} \mathrm{O}_{2}$ & $77 \pm 33$ & $91 \pm 2$ & $93 \pm 3$ \\
\hline \multirow{3}{*}{ BuprenorphineD10 } & $\mathrm{pH}$ & $7.39 \pm 0.01$ & $7.41 \pm 0.01$ & $7.40 \pm 0.01$ \\
\hline & $\mathrm{P}_{\mathrm{a}} \mathrm{CO}_{2}$ & $41+4$ & $41+3$ & $40 \pm 2$ \\
\hline & $\mathrm{P}_{\mathrm{a}} \mathrm{O}_{2}$ & $90 \pm 2$ & $92 \pm 3$ & $912 \pm 3$ \\
\hline \multirow{3}{*}{ MethadoneD10 } & $\mathrm{pH}$ & $7.39 \pm 0.01$ & $7.40 \pm 0.02$ & $7.40 \pm 0.01$ \\
\hline & $\mathrm{P}_{\mathrm{a}} \mathrm{CO}_{2}$ & $42 \pm 3$ & $43 \pm 5$ & $40 \pm 6$ \\
\hline & $\mathrm{P}_{\mathrm{a}} \mathrm{O}_{2}$ & $89+3$ & $93+2$ & $91+4$ \\
\hline \multirow{3}{*}{ 10\% Dextrose } & $\mathrm{pH}$ & $7.39 \pm 0.03$ & $7.40 \pm 0.02$ & $7.39 \pm 0.01$ \\
\hline & $\mathrm{P}_{\mathrm{a}} \mathrm{CO}_{2}$ & $42 \pm 4$ & $43 \pm 3$ & $41 \pm 0.9$ \\
\hline & $\mathrm{P}_{\mathrm{a}} \mathrm{O}_{2}$ & $91 \pm 3$ & $93 \pm 2$ & $95+4$ \\
\hline
\end{tabular}


hypercarbia have been reported after epidural opioid agonist administration in human beings (MUIR et al., 1978; HUBBELL, 1991; GOETZ et al., 1994). The respiratory depressant effects could occur within minutes to hours after neuraxial opioids in humans (CHUNG \& HARRIS, 1992; SINATRA et al., 1992). It can be explained by the cranial migration of the opioid in the CSF and its agonist effects on opioid receptors in the ventral medulla (COUSINS \& MATTER, 1984). In our study, the horses maintained all the respiratory parameters within normal range for the equine species (HUBBELL, 1991). We can explain the differences between the horses in our study and human beings regarding respiratory depression after spinal opioid agonist administration due to the segmental effect of the hyperbaric solutions we used and the standing position of our horses versus the recumbent position in humans.

Intravenous administration in horses of morphine-like opioid results in a drug-dependent increase in HR, CO, and MAP (KARMELING et al., 1988). Severe hypotension and cardiovascular collapse have occurred with spinal meperidine and a massive dose of epidural morphine has been reported to cause left bundle branch block in human beings (MASOUD \& GREEN, 1982; BALABAN \& SLINGER, 1989). A combination morphine and detomidine epidurally administered in horses produced significant decrease in HR (SYSEL et al., 1996). In another study, 0.06mg $\mathrm{kg}^{-1}$ detomidine produced significant decrease in HR and MAP from baseline data after an initial increase. Epidural detomidine may produce cardiovascular depression in horses by systemic absorption decreasing sympathetic outflow from the CNS, and to vagal reflex from baroreceptor response to initial hypertension (SKARDA \& MUIR, 1994). In our study we showed that epidural morphine does not depress the cardiovascular function. Differences in HR among treatment groups during the 24-hour period were not statistically significant. The compound U50488H produced the lowest rates although still within accepted range for horses. In horses, the dose of $0.08 \mathrm{mg} \mathrm{kg}^{-1} \mathrm{IV}$ U50488H did not change the cardiac rate for 60 minutes (KAMERLING et al., 1988). The differences in MAP observed in our study were not statistically significant from baseline or between groups and they were within the accepted range for the equine species (HUBBELL, 1991). We explain the lack of cardiovascular depression in our study based on the pharmacology and pharmacokinetics of subarachnoidally hyperbaric administered opioids that because of the higher baricity of the solution should maintain the drugs bound to the spinal cord receptors and avoid systemic absorption.
Epidural hydrophilic opioids administered such as morphine only cross the dura mater in about $3 \%$ of the total administered dose. It stays in the CSF for longer periods than methadone and migrate cephalad potentially depressing the respiration but cardiovascular side effects are produced rarely (COUSINS \& MATHER, 1984; MORGAN, 1989).

Our conclusion is that in the horse, subarachnoid hyperbaric administration of opioids produces no clinical significant cardiovascular, respiratory, nor locomotor adverse effect. As sedation and head ptosis are not produced with the dose rates used, morphine, buprenorphine, or methadone can be used safely.

\section{ACQUISITION SOURCES}

a - Bioclusiv, transparent dressing, Johnson \& Johnson Medical Inc. Arlington, TX.

b - Reusable Technique needle, Tuohy, thin wall, Becton Dickinson and Co. Franklin Lakes, NJ.

c - Arrow Epidural Anesthesia Catheter, Arrow International, Reading, PA 19605.

d - Infumorph ${ }^{\circledR}$ 200, Elkin-Sinn, Cherry Hill, NJ.

e - Buprenorphine - Buprenex 0.3mg/ml Reckitt and Coleman Pharmaceuticals Ltd. Richmond, VA 23235.

f - Methadone - Methadone Hydrochloride $10 \mathrm{mg}$ per mL, / Alpharma, Inc; Lincolnton, NC. 27410.

g - Dextrose 10\% - The Butler Company Dublin, OH 43017

\section{REFERENCES}

BALABAN, M.; SLINGER, P. Severe hypotension from epidural meperidine in a high-risk patient after thoracotomy. Canadian Journal of Anesthesiology, Toronto v.36, p.450-453, 1989.

CHENG, J.K. et al. Epidural phenylephrine attenuates hypotension induced by alkalinized lidocaine epidural anesthesia. Anesthesia and Analgesia, Baltimore, v.88, p.1322-1326, 1999.

CHUNG, J.H; HARRIS, S.N. Common side effects associated with spinal opoids and their treatment. In: SINATRA, R.S. et al. Acute pain: mechanisms and management. St Louis: Mosby-Year, 1992. Cap.2, p.279-292.

COMBIE, J. et al. The pharmacology of narcotic analgesics in the horse. IV. Dose and time response relationships for behavioral responses to morphine, meperidine, pentazocine, anileridine, methadone, and hydromorphone. Journal of Equine Medicine and Surgery, Philadelphia v.3, p.377-385, 1979.

COMBIE, J. et al. Pharmacology of narcotic analgesics in the horse: selective blockade of narcotic-induced locomotor activity. American Journal of Veterinary Research, Chicago, v.42, p.716-721, 1981.

COUSINS, M.J; MATHER, L.E. Intrathecal and epidural administration of opioids. Anesthesiology, Philadelphia, v.61, p.276-310, 1984.

Ciência Rural, v.36, n.5, set-out, 2006. 
GOETZ, A.M. et al. Adult respiratory distress syndrome associated with epidural fentanyl infusion. In: Critical Care Medicine. New York: Williams \& Wilkins, 1994. Cap.22, p.1579-1583.

GÓMEZ DE SEGURA, I.A. et al. Epidural injection of ketamine for perineal analgesia in the horse. Veterinary Surgery, Philadelphia, v.27, p.384-391, 1998.

GRUBB, T.L. et al. Comparison of lidocaine, xylazine, and xylazine/lidocaine for caudal epidural analgesia in horses. Journal of the American Veterinary Medical Association, Ithaca, v.201, p.1187-1190, 1992.

HUBBELL, J.A.E. Monitoring. In: MUIR, W.W; HUBBELL, J.A.E. Equine anesthesia. St. Louis: Mosby, 1991. Cap. 5, p.157-158.

KARMERLING, S. et al. Dose-related effects of fentanyl on autonomic and behavioral responses in performance horses. General Pharmacology, New York, v.16, p.253-258, 1985.

KARMELING, S. et al. Dose related effects of the kappa agonist U-50488H on the behaviour, nociception and autonomic response in the horse. Equine Veterinary Journal, London, v.20, p.114-118, 1988

LeBLANC, P.H; CARON, J.P. Clinical use of epidural xylazine in the horse. Equine Veterinary Journal, London, v.22, p.180-181, 1990.

LeBLANC, P.H; EBERHART, S.W. Cardiopulmonary effects of epidurally administered xylazine in the horse. Equine Veterinary Journal, London, v.22, p.389-391, 1990.

MAMA, K.R. et al. Evaluation of the interaction of $\mathrm{Mu}$ and Kappa opioid agonists on locomotor behavior in the horse. Canadian Veterinary Journal, Gardenvale, v.57, p.106109, 1992.

MASOUD, P.J; GREEN, C.D. Effects of massive overdose of epidural morphine sulphate. Canadian Anesthesia Society, Toronto, v.29, p.377-380, 1982

McLEOD, W.M; FRANK, E.R. A preliminary report regarding epidural anesthesia in equines and bovines. Journal of the American Veterinary Medical Association, Ithaca, v.72, p.327-335, 1927.

MORGAN, M. The rational use of intrathecal and extradural opioids. British Journal of Anaesthesia, London, v.63, p.165-188, 1989

MUIR, W.W. et al. Cardiopulmonary effects of narcotic agonists and a partial agonist in horses. American Journal of Veterinary Research, Chicago, v.39, p.1632-1635, 1978.

NATALINI, C.C; ROBINSON, E.P. Comparative evaluation of the analgesic effects of epidural morphine, alfentanil, butorphanol, tramadol, and U50488H in horses. American Journal of Veterinary Research, Chicago, v.61, p.15791586, 2000

PABLO, L.S. Epidural morphine in goats after hindlimb orthopedic surgery. Veterinary Surgery, Philadelphia, v.22, p.141-147, 1993.
PADDLEFORD, R.R. Manual of small animal anesthesia. Philadelphia: Saunders, 1999. 957p.

PAPE, J; PITZSCHK, C. Versuche uber extradurale Anasthesie beim pferde. Arch Wiss Prakt Tierheilkd, Berlim, v.52, p.558-571, 1925.

SINATRA, R.S. et al. Acute pain: mechanisms and management. St Louis: Mosby-Year, 1992. 1302p.

SKARDA, R.T; MUIR, W.W. Caudal analgesia induced by epidural or subarachnoid administration of detomidine hydrochloride solution in mares. American Journal of Veterinary Research, Chicago, v.55, p.670-680, 1994.

SKARDA, R.T; MUIR, W.W. Comparison of antinociceptive, cardiovascular, and respiratory effects, head ptosis, and position of pelvic limbs in mares after caudal epidural administration of xylazine and detomidine hydrochloride solution. American Journal of Veterinary Research, Chicago, v.57, p.13381345, 1996

SKARDA, R.T. Local and regional anesthetic and analgesic techniques. In: THURMON, J.C. et al. Lumb \& Jone's veterinary Anesthesia. Baltimore: Williams \& Wilkins, 1996. Cap.7, p.448-478.

STOELTING, R.K. Pharmacology and physiology in anesthetic practice. Philadelphia: Lippincott-Raven, 1999. 639p.

SYSEL, A.M. et al. Efficacy of an epidural combination of morphine and detomidine in alleviating experimentally induced hindlimb lameness in horses. Veterinary Surgery, Philadelphia, v.25, p.511-518, 1996.

THURMON, J.C. et al. Lumb \& Jones' Veterinary Anesthesia. Baltimore: Williams \& Wilkins, 1996. 928p.

TOBIN, T. Narcotic analgesics and the opiate receptor in the horse. Journal of Equine Medicine and Surgery, Philadelphia v.2, p.397-399, 1978.

TOBIN, T; MILLER, J.R. The pharmacology of narcotic analgesics in the horse. I. The detection, pharmacokinetics and urinary clearance times of pentazocine. Journal of Equine Medicine and Surgery, Philadelphia v.3, p.191-198, 1979.

TOBIN, T. et al. Pharmacology review: actions of central stimulant drugs in the horse. II. Journal of Equine Medicine and Surgery, Philadelphia v.3, p.102-109, 1979

TOBIN, T. et al. The pharmacology of narcotic analgesics in the horse. III. Characteristics of the locomotor effects of fentanyl and apomorphine. Journal of Equine Medicine and Surgery, Philadelphia v.3, p.284-288. 1979

TOBIN, T. Drugs and the performance horse. Springfield: Charles C. Thomas, 1981. 330p.

VALVERDE, A. et al. Use of epidural morphine to relieve pain in a horse. Canadian Veterinary Journal, Gardenvale, v.31, p.211-212, 1990.

WITTERN, C. et al. Complications associated with administration of detomidine into the caudal epidural space in a horse. Journal of the American Veterinary Medical Association, Ithaca, v.213, p.516-518, 1998.

Ciência Rural, v.36, n.5, set-out, 2006. 